\title{
COMPARATIVE APPROACH OF THE SOLUBILITY OF PROTACTINIUM OXY/HYDROXIDES
}

\author{
P. Tarapcik ${ }^{1}$, B. Fourest ${ }^{2}$, E. Giffaut ${ }^{3}$ \\ ${ }^{1}$ Slovak Technical University, Faculty of Chemical and Food Technology, \\ Department of Analytical Chemistry, Radlinského 9, 81237, Bratislava, Slovakia \\ ${ }^{2}$ IPN, Groupe de Radiochimie, 91406 Orsay Cedex, France \\ tel. : 0169157485 - fax : 0169156470 - e-mail : fourest@ipno.in2p3.fr \\ ${ }^{3}$ ANDRA DS/MA, 92298 Châtenay-Malabry Cedex, France
}

\begin{abstract}
The hydrolysis constants and the solubility products of the oxide/hydroxides of $\mathrm{Pa}(\mathrm{IV})$ and $\mathrm{Pa}(\mathrm{V})$ have been first reviewed and re-evaluated through the application of three comparative methods : the simple Hard Sphere Electrostatic model (HSE), the Brown and Wanner Theory (BWT) and the Correlation between Solubility and Complex stability constants of a metal ion (CSC). The latter method is the most empirical one, but it gives coherent results, in agreement with the few published experimental values, for all the possible aqua species of protactinium $\left(\mathrm{Pa}^{4+}, \mathrm{Pa}^{5+}, \mathrm{PaO}_{2}{ }^{+}\right.$and $\left.\mathrm{PaO}^{3+}\right)$. The selected thermodynamic data have then been used to predict the protactinium solubility in non complexing media of various $\mathrm{pH}$ and redox potential.
\end{abstract}

\section{KEY WORDS}

Protactinium, solubility, oxides, hydroxides, hydrolysis, correlations, models. 


\section{I - INTRODUCTION}

Very few experimental studies deal with the solubility of the oxides and hydroxides of protactinium, both for $\mathrm{Pa}(\mathrm{IV})$ and $\mathrm{Pa}(\mathrm{V})$.

Concerning $\mathrm{Pa}(\mathrm{V})$, the only one value of solubility product $\left(\mathrm{K}_{\mathrm{s}}\right)$ available in the literature is based on the very old work of Starik [1]. Assuming that the equilibrium to be considered at a $\mathrm{pH}$ value of 5 involves $\mathrm{Pa}(\mathrm{OH})_{5}$ for the solid phase and $\mathrm{Pa}^{5+}$ for the soluble species in solution (its composition is not defined), a $\mathrm{K}_{\mathrm{s}}$ value of $10^{-55}$ at zero ionic strength is proposed (equilibrium $\mathrm{Pa}^{5+}+5 \mathrm{OH}^{+} \Leftrightarrow \mathrm{Pa}(\mathrm{OH})_{5}$ ). This value, re-calculated for the most probable system $\mathrm{PaO}(\mathrm{OH})_{3} / \mathrm{PaO}^{3+}\left(\mathrm{PaO}^{3+}+3 \mathrm{OH}^{+} \Leftrightarrow \mathrm{PaO}(\mathrm{OH})_{3}\right)$, becomes $10^{-34}$ and, for the system $\mathrm{PaO}_{2}(\mathrm{OH}) / \mathrm{PaO}_{2}{ }^{3+}\left(\mathrm{PaO}_{2}{ }^{3+}+\mathrm{OH}^{+} \Leftrightarrow \mathrm{PaO}_{2}(\mathrm{OH})\right)$, around $10^{-20}$. About the latter system, Muxart and Guillaumont [2] have proposed a limit value of around $10^{-16}$, which is the value given in the collections of equilibrium constants [3,4] and in the book of Baes and Mesmer [5].

The solubility product obtained for $\mathrm{Pa}(\mathrm{IV})$ by Muxart and Guillaumont [2] is $10^{-53,4}$ at zero ionic strength and corresponds to the system $\mathrm{Pa}(\mathrm{OH})_{4} /\left(\mathrm{Pa}^{4+}\right.$ (equilibrium $\mathrm{Pa}^{4+}+4 \mathrm{OH}^{+}$ $\left.\Leftrightarrow \mathrm{Pa}(\mathrm{OH})_{4}\right)$. However this value should be taken with caution, owing to the difficulties encountered during the experiments due to the strong tendency of protactinium(IV) to polymerize and to be sorbed.

Moreover, the redox potential of the system $\mathrm{Pa}(\mathrm{V}) / \mathrm{Pa}(\mathrm{IV})$ has been recently revised by Guillaumont et al. [6]. The only reliable data are supplied by Bratsh [7] and Morss [8]. The standard potential of the equilibrium $\mathrm{PaO}(\mathrm{OH})^{2+}+\mathrm{e}^{-}+3 \mathrm{H}^{+} \Leftrightarrow \mathrm{Pa}^{4+}+2 \mathrm{H}_{2} \mathrm{O}$ is thus given equal to $-0,1 \mathrm{~V} / \mathrm{SHE}$. 
Because of this lack of experimental data, the use of predictive models appears as a necessity, which should have a double objective: to judge the availability of published data and to fill the gaps. Only semi-empirical methods can really be applied. They are generally based on a comparison of thermodynamic properties of similar elements in connection, most often, with the bond energy of the ligand. This kind of approach has already been used in order to interpolate stepwise constants or to extrapolate constants from a known to an unknown system ([9], ref. 2-8 cited in [10],[11]). The following models can be distinguished:

- the simple hard sphere electrostatic model (HSE), which can be useful for some restricted applications and in the case of very similar ions [12].

- the unified theory of metal ion complex formation developed by Brown and Wanner [13] (BWT), which completes the electrostatic interaction by taking into account structural aspects of the outermost shell. However, the choice of some parameters to be introduced (ionic radii) or considered (coordination number, electronic structure of the cation) can pose a problem.

- the procedure based on the fact that, for a given ligand, solubility and complex formation of a metal ion are often correlated. Uncertainty or subjectivity of choosing some parameters of the system (as mentioned above for Brown model) as well as too large simplifications (electrostatic model) are thus eliminated. But the knowledge of one good value is necessary to estimate the second one.

The three methods have been applied in order to have a critical view of hydrolysis and solubility of $\mathrm{Pa}(\mathrm{IV})$ and $\mathrm{Pa}(\mathrm{V})$. From the selected data, solubility curves in non complexing media can be plotted. 


\section{II - MODELS AND FITTING PROCEDURE}

\section{II-1 : Electrostatic model (HSE)}

In this method, the central atom and ligands are considered as hard spheres having electric charges interacting only by Coulomb interactions. Solvation and entropic effect are neglected in this simple model. It has already been used to predict constants for hydrolysis and carbonate complexation of transuranium elements [12]. It has been applied as follows :

Since RT Ln $\beta^{\circ}=\Delta E=1 / \varepsilon\left(\Sigma Z_{i 1} Z_{j 1} / r_{i j 1}-\Sigma Z_{i 2} Z_{j 2} / r_{i j 2}\right)$

state 1 referring to the aqua ion and state 2 to the complex under consideration,

we can write, by setting $\mathrm{Q}=\left(\Sigma \mathrm{Z}_{\mathrm{i} 1} \mathrm{Z}_{\mathrm{j} 1} / \mathrm{r}_{\mathrm{ij} 1}-\Sigma \mathrm{Z}_{\mathrm{i} 2} \mathrm{Z}_{\mathrm{j} 2} / \mathrm{r}_{\mathrm{ij} 2}\right)$

$\log \beta^{\circ}=\mathrm{Q} / \mathrm{K}$

In the above equations, $\mathrm{R}$ denotes the gas constant, $\mathrm{T}$ the absolute temperature, $\mathrm{E}$ the electrostatic potential energy, $\varepsilon$ the dielectric constant, $Z_{i}$ and $Z_{j}$ the electric charges of the hard spheres $\mathrm{i}$ and $\mathrm{j}$, respectively, and $\mathrm{r}_{\mathrm{ij}}$ the distance between the hard spheres $\mathrm{i}$ and $\mathrm{j}$. The distances were obtained from ionic radii and space configuration.

Constant $\mathrm{K}$ has been evaluated from known stability constants, concerning $\mathrm{Np}, \mathrm{Pu}, \mathrm{Pa}$, $\mathrm{U}, \mathrm{Ce}, \mathrm{Hf}, \mathrm{Th}, \mathrm{Ti}, \mathrm{Sn}$ and $\mathrm{Zr}$, for the tetravalent ions, and $\mathrm{Pa}, \mathrm{Pu}, \mathrm{Np}, \mathrm{V}$ and $\mathrm{Nb}$ for the $\mathrm{MO}_{2}{ }^{+}$ions (oxidation degree 5) for which input data were available.

$\mathrm{X}$ values have been calculated for an octahedral geometry. The ionic radii at the coordination 6 come from the work of Shannon [14]. $\mathrm{H}_{2} \mathrm{O}$ is considered as a charged ligand because of the dipolar interaction and the data involving $\mathrm{H}_{2} \mathrm{O}, \mathrm{OH}^{-}$and $\mathrm{O}^{2-}$ are those mentioned in [12].

The limit values of the stability constants are extracted from the Kotrly collection [3] and correspond, for most of them, to the data collected by Brown and Wanner [13]. The solubility products of the hydroxo compounds have been treated as hydrolysis constants. In 
fact, the method consists in correlating stability constants to interatomic distances through Coulomb Law. This does not mean that electrostatics is enough for a narrow prediction of equilibrium constants, but there is some chance to derive correct data in a group of similar ions or by using additional parameters in the empirical formula.

\section{II-2 : Brown-Wanner Theory (BWT)}

The method developed by Brown and Wanner relates the stability constants of hydroxo complexes [10] or other complexes [13] to some parameters of the central atom and ligands, which are in turn related to the bond energy (essentially electrostatic with some aspects of the outermost shell taken into account). This method comprises also some weak points. For example, the interaction with the first ligand is assumed identical to the interactions with higher order ligands, without mutual interference. The electrostatic repulsion contribution is qualitatively included in BWT only as a statistical phenomenon through the Bjerrum ratios of consecutive formation constants.

However, Brown-Wanner method can be useful not as « unified theory» but separately in area of distinct number of ligands.

For monomer complexes, $\log \beta_{\mathrm{i}}$ varies linearly with parameter $(\mathrm{X})$ depending on the charge and the radius of the central ion, and on functions defined by the structure of the electron shell of the ion. More details can be found in the original sources [13].

In order to test the method, we have first plotted the data reported by Brown and Wanner on hydrolysis, as a function of the corresponding experimental data proposed in the literature (sources : [3 - 5, 14 -16], [17] for Am and [18] for Np). The BWT works well for $\beta_{1}$, except in the case of tetravalent elements and $\mathrm{PaO}_{2}{ }^{+}$, also for $\beta_{2}$ and $\beta_{3}$ but data are less numerous. For $\beta_{4}$ the number of examined data is too low. 
In order to improve the fitting we have re-determined the X-parameter value. Data used in this aim are collected in Table 1. They have been selected in such order that the best linearity is obtained for the $\log \beta_{\mathrm{i}}$ versus $\mathrm{X}$ variations. Ionic radii data are, for most of them, the values proposed by Shannon [19]. They are completed or replaced by data found in [20], [21] and [22]. When they exist, stability constants are chosen already extrapolated to zero ionic strength and, if possible, with a $\mathrm{K}_{\mathrm{s}}$ value associated to them (references $[3,4,5,14,16]$, unless specified). In some cases, Specific Interaction Theory (SIT) [23, 25] has been used to extrapolate the constant to infinite dilution. The equilibrium constants from reviews were used only when they originated from a real determination, and not from any estimation.

\section{II-3 : Correlation with hydrolysis (CSC)}

A linear correlation can be expected between $\log K_{\mathrm{s}}$ and $\log \beta_{\mathrm{n}}$, and the value $\mathrm{K}_{\mathrm{s}}$ can be deduced from $\beta_{\mathrm{n}}$ and conversely. We applied the correlation either to a group of ions presenting the same charge $\mathrm{z}$ or to the same number of bonds $-\log \mathrm{K}_{1} \mathrm{vs} \log \mathrm{K}_{\mathrm{s}} / \mathrm{z}$ and so on.

However, the first approach will be shown to give good results only for $\mathrm{n}=\mathrm{z}$ and the second approach is not quite correct because repulsion forces depend on $\mathrm{z}$ and, consequently, an average value obtained by dividing by $\mathrm{z}$ can only be an approximation. This has been empirically corrected in the present work by adopting the following linear correlation :

$-\log K_{\mathrm{s}}$ vs. $q_{i}(z / i) \log \beta_{i}$

$\mathrm{i}$ denoting the number of bonds and $\mathrm{q}_{\mathrm{i}}$ an empirical factor which originates from the ratio between two consecutive steps of the complex formation. Thus the overall values of $\beta$ can be used in one common correlation. However, as $\beta_{1}$ is the constant measured with the highest precision and for the highest number of ions, it is appropriate to test first the linear correlation $-(1 / \mathrm{z}) \log \mathrm{K}_{\mathrm{s}}$ vs. $\log \beta_{1}$. 
A further development of the correlation $\mathrm{K}_{\mathrm{s}} / \beta$ will consist of grouping ions according to their structural parameters, with use of more defined $q_{i}$ values, or of looking for the influence of the solid lattice structure in order to import some corrections on this base.

\section{III - RESULTS}

\section{III-1 : HSE}

\section{Case of tetravalent species}

Except for titanium, the HSE method gives good results, specially for the two first hydrolysis constants (the constant $\mathrm{K}$ in eq. 3 is defined with an uncertainty of $5 \%$ for $\log \beta_{1}$ and $\log \beta_{2}$, $6 \%$ for $\log \beta_{3}$ and $\log K_{s}, 6.5 \%$ for $\log \beta_{4}$ ). In the case of $P a$, the value of calculated $\log K_{s}$ is equal to -52.88 , which is to be compared with the experimental value of -53.4 . Even if improvements are still possible (new experimental data can be introduced, concerning, for example, lead), the HSE method tends to provide $\mathrm{K}_{\mathrm{s}}$ values very close for all the elements under consideration (- $\log \mathrm{K}_{\mathrm{s}}$ is ranging between 51.98 and 54.79). Moreover, no prediction can be attempted for the oxo-ions $\mathrm{MO}^{2+}$ due to the lack of experimental data corresponding to this kind of ions.

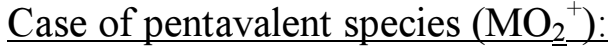

Even in the case of $\beta_{1}$, which is a constant known for all the elements under consideration $(\mathrm{Pa}, \mathrm{Pu}, \mathrm{Np}, \mathrm{V}$ and $\mathrm{Nb})$, the $\mathrm{K}$ values are too scattered to allow predictive calculations. A comparison limited to vanadium only, leads to calculate a $-\log \mathrm{K}_{\mathrm{s}}$ value equal to 11.96 as well as the values of the following constants:

$\log \beta_{1}=9.59, \log \beta_{2}=18.56$ 
The $\log \beta_{1}$ and $\log \mathrm{K}_{\mathrm{s}}$ values of $\mathrm{Pu}(\mathrm{V})$ and $\mathrm{Np}(\mathrm{V})$ are also known, but completely inconsistent with those of vanadium (and niobium). If taken as a separate group of actinides, they give for protactinium values incompatible with experimental data and another predictions $\left(\log \beta_{1}=4.6\right.$ and $\left.\log K_{\mathrm{s}}=8.8\right)$

\section{III-2 : BWT}

The linearity of the curves $\log \beta_{i}=f(X)$ and $\log K_{s}=f(X)$ (plotted, as an example, in Fig. 1) shows that:

The Brown-Wanner theory is working for $\mathrm{M}^{+}, \mathrm{M}^{2+}, \mathrm{M}^{3+}$ and $\mathrm{M}^{4+}$ ions within range $\pm 1-1.5$ for $\log \beta_{1}, \pm 1.5$ for $\log \beta_{2}, \pm 2-3$ for $\log \beta_{3}, \pm 5$ for $\log \beta_{4}$ and \pm 5 for $\log \mathrm{K}_{\mathrm{s}}$. Unfortunately, we did not succeed in applying it to oxo ions. in the case of $\mathrm{Pa}^{4+}, \mathrm{d}$ and $\mathrm{f}$ orbitals have been assumed to be equivalent (this leads to a $\log \beta_{1}$ value well positioned on the straight line $\log \beta_{1}$ vs $X$ ). The results are collected in Table 2 .

A set of constants can also be derived for $\mathrm{Pa}^{5+}\left(\log \beta_{1}=18.97 / 23.09, \log \beta_{2}\right.$ $=36.53 / 44.46, \log \beta_{3}=49.88 / 60.71, \log \beta_{4}=60.42 / 73.53$ and $\log K_{s}=$ $63.23 / 76.95$ for $\mathrm{X}=140.5(\mathrm{r}=91 \AA) / 171(\mathrm{r}=78 \AA)$ respectively) but the values so-determined are purely theoretical since $\mathrm{Pa}(\mathrm{V})$ is expected to exist in solution only as an oxo-ion. Besides the theoretical character, we can note that: 1) the distribution of hydrolysed species based on these constants show that the first and second steps of hydrolysis are almost complete even if the concentration of acid is $1-6 \mathrm{M}$ (about $90 \%$ as $3+$ ion), $2+$ ion prevails at $\mathrm{pH}$ 2.5 and $1+$ at 4.4 , electrically uncharged species exist at $\mathrm{pH} 6$ and completely negative at $\mathrm{pH} 9 ; 2$ ) these constants can serve also as source for deriving stepwise hydrolysis constants. 
- It is also possible to predict hydrolysis constants of higher order from the linear or non linear relationships between $\log \beta_{i}$ and $i$. The results are as follows for $\mathrm{Pa}^{4+}: \log \beta_{5}=58.6$ or 55.1 and $\log \beta_{6}=68.4$ or 62.8 ; for the "theoretical" $\mathrm{Pa}^{5+}: \log \beta_{5}=79.9 / 92.3$ and $\log \beta_{6}=88.5 / 107.7\left(\log \beta_{5}=67.4\right.$ / 82.1 and $\log \beta_{6}=73.1 / 88.9$ from non linear extrapolation). These data are useful to judge the behavior of $\mathrm{Pa}(\mathrm{V})$ in basic solutions.

- $\quad$ Brown et al [13] did not describe in details how to calculate the parameter X for oxo ions; the size, effective charge and structure to be used are questionable.

\section{III-3 : CSC}

\section{Case of tetravalent elements:}

The $\log \mathrm{K}_{\mathrm{s}} / \mathrm{z}$ vs $\log \beta_{\mathrm{i}}$ and $\log \mathrm{K}_{\mathrm{s}} \mathrm{vs} \log \beta_{\mathrm{n}}$ variations show that, in the former case, $\mathrm{a}$ relatively good correlation is obtained (less good than from the Brown-Wanner theory for the two first steps, better for the following ones) and, in the latter case, excellent and comparable with that of Brown-Wanner (see Fig. 2). If all the bonded $\mathrm{OH}$ were equivalent, a single straight line would be expected for $\log K_{\mathrm{s}} / \mathrm{z}$ vs $\log \beta_{\mathrm{i}}$. In reality, the slope is observed to decrease from $\beta_{1}$ to $\beta_{\mathrm{n}}$.

We have used the graphs as follows: first, the best measured constant is chosen. If it is $\mathrm{K}_{\mathrm{s}}$, the $\beta_{\mathrm{i}}$ values are then directly derived from the curves $\log \mathrm{K}_{\mathrm{s}} / \mathrm{z}$ vs $\log \beta_{\mathrm{i}}$. If it is $\beta_{1}$ (the most probable case), $K_{s}$ is first deduced from the curve $\log K_{s}$ or $\log K_{s} / z$ vs $\log \beta_{1}$, then the hydrolysis constants of higher order are deduced in turn. The results concerning protactinium are collected in Table 2 , the data initially chosen for estimates in given column being in bold. 


\section{Case of oxo-ions:}

Oxo-ions represent a special problem and have to be treated separately because:

- $\quad$ very few ions are concerned and the corresponding thermodynamic data are scarce.

- $\quad$ two forms have been assumed for $\mathrm{Pa}(\mathrm{V}): \mathrm{PaO}_{2}{ }^{+}$and $/$or $\mathrm{PaO}^{3+}$.

The variation $\log \mathrm{K}_{\mathrm{s}} / \mathrm{z}$ vs $\log \beta_{1}$ presents a good linearity in the whole group of oxo ions, but the value of protactinium $\left(\mathrm{K}_{\mathrm{s}}\left(\mathrm{PaO}_{2} \mathrm{OH}\right)=10^{-16}\right)$, is the only value very distant from the line. However, this $\mathrm{K}_{\mathrm{s}}$ value given for $\mathrm{Pa}(\mathrm{V})$ is, as explained in Introduction, subject to discussion. If the value of $10^{-34}$ is chosen for $\mathrm{K}_{\mathrm{s}}$ of $\mathrm{PaO}(\mathrm{OH})_{3}, \log \mathrm{K}_{\mathrm{s}} / \mathrm{z}$ is equal to 11.3 , in total agreement with the line. This supports the opinion about the existence of $\mathrm{PaO}(\mathrm{OH})_{2}{ }^{+}$rather than $\mathrm{PaO}_{2}^{+}$. This phenomenon can also be explained by incorrect $\log \mathrm{K}_{\mathrm{s}}$ or $\log \beta_{1}$ experimental data. An experimental verification is required.

Since the values of $\log K_{\mathrm{s}}=-34$ and $\log \beta_{1}=8$ can be considered as consistent with other values of this type, the following data have been deduced from the variations $\log \mathrm{K}_{\mathrm{s}}=$ vs $\log \beta_{\mathrm{i}}$, with $\log \mathrm{K}_{\mathrm{s}}=-34$ for $\mathrm{PaO}^{3+}$ and -16 for $\mathrm{PaO}_{2}{ }^{+}$as starting values: for $\mathrm{PaO}^{3+}: \log \beta_{1}$ $=10.4, \log \beta_{2}=19.7, \log \beta_{3}=27, \log \beta_{4}=34.5 ;$ for $\mathrm{PaO}_{2}{ }^{+}: \log \beta_{1}=10, \log \beta_{2}=19.1, \log \beta_{3}$ $=25$. The values $\log \beta_{3}=27$ for $\mathrm{PaO}^{3+}$ and $\log \beta_{1}=10$ for $\mathrm{PaO}_{2}{ }^{+}$were obtained from partial correlation $\log \mathrm{K}_{\mathrm{s}} \mathrm{vs} \log \beta_{\mathrm{i}}$ and the other ones from an overall line using appropriate $\mathrm{q}_{\mathrm{i}}$ values. 


\section{III-4 : Synthesis of the results}

\section{Case of $\mathrm{Pa}(\mathrm{IV})$}

Our predictions concerning both the hydrolysis and solubility constants of $\mathrm{Pa}(\mathrm{IV})$ are collected in Table 2. The best agreement with all the experimental data is obtained by using the HSE method for the calculations.

We can also remark that the Brown-Wanner method gives the closest hydrolysis constants compared to experimental data, but this is not true for the solubility product.

\section{Case of $\mathrm{Pa}(\mathrm{V})$}

As seen above, the Brown-Wanner theory can only be applied to the «theoretical» system $\mathrm{Pa}^{5+}-\mathrm{OH}^{-}$, but the degree of dehydration of the species is questionable and some ionic parameters very uncertain. However, the constants can be used for stepwise equilibria, e.g. as

$\mathrm{PaO}^{3+}+\mathrm{OH}^{-} \Leftrightarrow \mathrm{PaO}(\mathrm{OH})^{2+}$ with $\log \mathrm{K}_{1}=\log \beta_{3}{ }^{*}-\log \beta_{2}{ }^{*}=49.88-36.53=13.35$ or as:

$\mathrm{PaO}^{3+}+\mathrm{H}_{2} \mathrm{O} \Leftrightarrow \mathrm{PaO}(\mathrm{OH})^{2+}+\mathrm{H}^{+}$with $\log \mathrm{K}_{\mathrm{h} 1}=\log \beta_{3}{ }^{*}-\log \beta_{2}{ }^{*}-\log \mathrm{K}_{\mathrm{w}}=49.88-$ $36.53-14=-0.65$

These values are valid for an ionic radius $r=91 \AA$; the values for $r=78 \AA$ are 16.25 and 2.25. The designation $\beta_{\mathrm{i}}{ }^{*}$ means i-step of complexation starting from $\mathrm{Pa}^{5+}$.

Also:

$\mathrm{PaO}(\mathrm{OH})^{2+}+\mathrm{OH}^{-} \Leftrightarrow \mathrm{PaO}(\mathrm{OH})_{2}{ }^{+}$with $\log \mathrm{K}_{2}=\log \beta_{4}{ }^{*}-\log \beta_{3}{ }^{*}=60.42-49.88=10.54$ or as:

$\mathrm{PaO}(\mathrm{OH})^{2+}+\mathrm{H}_{2} \mathrm{O} \Leftrightarrow \mathrm{PaO}(\mathrm{OH})_{2}{ }^{+}+\mathrm{H}^{+}$with $\log \mathrm{K}_{\mathrm{h} 2}=\log \beta_{4}{ }^{*}-\log \beta_{3}{ }^{*}-\log \mathrm{K}_{\mathrm{w}}=60.42$ $-49.88-14=-3.46$ 
These values are valid for an ionic radius $r=91 \AA$; the values for $r=78 \AA$ are 12.82 and 1.18.

Predictions through the HSE method are not possible for $\mathrm{PaO}^{3+}$, because no ion of the same structure can be used as analogue. The empirical approach, which consists of correlating solubility and hydrolysis constants, gives a $\mathrm{K}_{\mathrm{s}}$ value of $\mathrm{PaO}^{3+}$ in agreement with the proposed value of $10^{-34}$

For $\mathrm{PaO}_{2}{ }^{+}$, the HSE method is limited by a comparison with vanadium only: the constants so-obtained can be compared to the experimental data, except for $\mathrm{K}_{\mathrm{s}}$. The comparison with $\mathrm{Pu}$ and $\mathrm{Np}$ in this case suggests that the method, used experimental data or existence of $\mathrm{PaO}_{2}{ }^{+}$ion are suspicious. Correlation with hydrolysis leads, in return, to values similar to experimental data, without changing $\mathrm{K}_{\mathrm{s}}$.

Moreover, it should be noted that the predicted values collected in Table 3 are obtained on the basis of data known with a large uncertainty. This is particularly true for the first hydrolysis constants. It is thus interesting to compare, for example, the constant recently published by Trubert et al. [24] for the equilibrium: $\mathrm{PaO}(\mathrm{OH})^{2+}+\mathrm{H}_{2} \mathrm{O} \Leftrightarrow \mathrm{PaO}(\mathrm{OH})_{2}{ }^{+}+$ $\mathrm{H}^{+}\left(\log \mathrm{K}_{\mathrm{h} 2}{ }^{\circ}=-1.27 \pm 0.15\right)$ to the equivalent value deduced from: $\log \beta_{2}^{* *}-\log \beta_{1}^{* *}-\log$ $\mathrm{K}_{\mathrm{w}}=19.7-10.4-14=-4.7$ (according to the CSC method, the designation $\beta_{\mathrm{i}}^{* *}$ means i-step of complexation starting from $\mathrm{PaO}^{3+}$ ). The difference is important (3.4 log units), but from the BWT method, two possible $\mathrm{K}_{\mathrm{h} 2}$ values can be derived, depending on the ionic radii used for $\mathrm{X}$. The first one is closer to the CSC predicted value and the second one is in agreement with the value published in [24].

Considering now the following equilibrium: $\mathrm{PaO}(\mathrm{OH})_{2}{ }^{+}+2 \mathrm{H}_{2} \mathrm{O} \Leftrightarrow \mathrm{Pa}(\mathrm{OH})_{5}+\mathrm{H}^{+}$ also investigated through extraction experiments in [24], the measured value of $\log \mathrm{K}_{\mathrm{h} 3}{ }^{\circ}(-$ $7.15 \pm 0.4)$ appears not too far from that deduced, in the present work, from the CSC method 
(-6.7) and the BWT method (-7.02) using a ionic radius of $91 \AA$ (the constant becomes equal to -5.43 with a ionic radius of $78 \AA$ ).

At last, the formation of a negatively charged species was pointed out in basic media through diffusion experiments: $\log K_{\mathrm{h} 4}=-9.03 \pm 0.1$ at $\left.\mathrm{I}=0.5\right)$ [25] leading to the following estimation of $\log \mathrm{K}_{\mathrm{h} 4}{ }^{\circ}=-8.78 \pm 0.1$. The predicted values at zero ionic strength corresponding to this equilibrium are -6.5 from the CSC method and -8.3 / -7.2 from the BWT method with ionic radii $91 \AA / 78 \AA$. From the above comparisons, it can be concluded that, in the case of $\mathrm{Pa}(\mathrm{V})$, the values obtained from the BWT method with a ionic radius of $91 \AA$ are consistent with the values derived from the CSC method and also with the experimental data, except for $\mathrm{K}_{\mathrm{h} 2}$.

\section{IV - SOLUBILITY IN NON COMPLEXING MEDIA}

From the thermodynamic data selected above (average values of Table 2 for $\mathrm{Pa}^{4+}$, values of $\beta_{1}$ and $\beta_{2}$ given in the $2^{\text {nd }}$ and $3^{\text {rd }}$ lines of Table 3 for $\mathrm{PaO}_{2}{ }^{+}$and $\mathrm{PaO}_{3}{ }^{+}$respectively), we can attempt to model Pa solubility in a non complexing medium $(\mathrm{I}=0.1)$, assuming that the species to be considered are:

- For $\mathrm{Pa}(\mathrm{IV}): \mathrm{Pa}^{4+}, \mathrm{Pa}(\mathrm{OH})^{3+}, \mathrm{Pa}(\mathrm{OH})_{2}{ }^{2+}, \mathrm{Pa}(\mathrm{OH})_{3}{ }^{+}, \mathrm{Pa}(\mathrm{OH})_{4}$, with the following equilibrium controlling solubility: $\mathrm{PaO}_{2}+2 \mathrm{H}_{2} \mathrm{O} \Leftrightarrow \mathrm{Pa}^{4+}+4 \mathrm{OH}^{-}$.

- For $\mathrm{Pa}(\mathrm{V}): \mathrm{PaO}^{3+}, \mathrm{PaO}(\mathrm{OH})^{2+}, \mathrm{PaO}_{2}{ }^{+}, \mathrm{PaO}_{2} \mathrm{OH}_{\mathrm{aq}}, \mathrm{PaO}_{2}(\mathrm{OH})_{2}^{-}$, with the following dissolution equilibrium: $\mathrm{Pa}_{2} \mathrm{O}_{5}+\mathrm{H}_{2} \mathrm{O} \Leftrightarrow 2 \mathrm{PaO}_{2}^{+}+2 \mathrm{OH}^{-} \quad\left(\log \mathrm{K}_{\mathrm{s}}=-16\right)$ and redox reaction: $\mathrm{PaO}(\mathrm{OH})^{2+}+3 \mathrm{H}^{+}+\mathrm{e}^{-} \Leftrightarrow \mathrm{Pa}^{4+}+2 \mathrm{H}_{2} \mathrm{O}\left(\mathrm{E}^{\circ}=-0.1 \mathrm{~V}\right)$

This configuration appears as the most probable, due to the accepted equilibrium: $\mathrm{PaO}(\mathrm{OH})^{2+} \Leftrightarrow \mathrm{PaO}_{2}^{+}+\mathrm{H}^{+}\left(\mathrm{K}_{\mathrm{x}}\right.$ constant given by Baes and Mesmer [5] and corrected to zero ionic strength : $\left.\log \mathrm{K}_{\mathrm{x}}{ }^{\circ}=0.09\right)$. A similar set of species of $\mathrm{Pa}(\mathrm{V})$ can be derived without the 
last mentioned equilibrium : $\mathrm{PaO}^{3+}, \mathrm{PaO}(\mathrm{OH})^{2+}, \mathrm{PaO}(\mathrm{OH})_{3}{ }^{+}, \mathrm{Pa}(\mathrm{OH})_{4, \mathrm{aq}}, \mathrm{PaO}(\mathrm{OH})_{3}{ }^{-}$. However, the configuration used in the present application can be easily modified if experiment justifies a change.

Polynuclear species are expected to play a role on the protactinium solubility. Depending on the way of determining $\mathrm{K}_{\mathrm{s}}$ value, calculated solubility can be over-estimated $\left(\mathrm{K}_{\mathrm{s}}\right.$ derived from the overall solubility) or under-estimated $\left(\mathrm{K}_{\mathrm{s}}\right.$ obtained by measuring the ions concentration in solution). However, these effects cannot be quantified and have been neglected in the present work.

Specific interaction theory has been applied to correct the thermodynamic constants (ionic strength chosen equal to 0.1), by using the coefficients given in [23, 25]. An Excel program has been written, which proceeds by steps and allows to plot, for given redox conditions, the speciation diagram of the different protactinium species involved as a function of $\mathrm{pH}$ as well as the resulting solubility curve. The three dimensions graph given on Fig. 3 shows how $\mathrm{pH}$ and redox conditions can influence protactinium solubility. Stability of water against reduction or oxidation is dependent on $\mathrm{pH}$. The validity of the graph is restricted in acidic solution at negative potential (evolution of hydrogen) and similarly in basic solution at high positive potential (formation of oxygen). The stability field for water can be found in $[26]$.

The first calculations reported in the present work show that protactinium solubility would be rather low, with protactinium concentrations close to $10^{-6} \mathrm{M}$ in solutions near neutrality and under oxidizing conditions. 


\section{V - COMPARISON WITH ACTINIDES(IV) AND (V)}

Besides, it is also interesting to compare the results of our calculations:

- to the data proposed in 1982 by Allard [27] (averages and probable limits) for actinides (except $\mathrm{Pa})$ :

$\mathrm{An}^{4+}: \log \beta_{1}=13.5(12.5-13.8) ; \log \beta_{2}=25.5 ; \log \beta_{3}=36.0 ; \log \beta_{4}=45.5 ; \log \beta_{5}$

$=50 ; \log \beta_{2.2}=27$ and $-\log \mathrm{K}_{\mathrm{s}}\left(\mathrm{AnO}_{2}\right)=54(47-64)$

$\mathrm{AnO}_{2}^{+}: \log \beta_{1}=4.6(4.0-5.1) ;-\log \mathrm{K}_{\mathrm{s}}\left(\mathrm{AnO}_{2} \mathrm{OH}\right)=8.8(8.5-9.3)$

- to those, reported on Table 4, already predicted for tetravalent actinides.

The $\log \mathrm{K}_{\mathrm{s}}$ value obtained in the present work for $\mathrm{Pa}^{4+}, 52.9$, by using the HSE model, is comprised in the expected interval. Such comparison is only conditional in the case of $\mathrm{Pa}(\mathrm{V})$. The more accepted starting aqua species is $\mathrm{PaO}^{3+}$, not comparable to other actinides. $\mathrm{PaO}_{2} \mathrm{OH}$ appears to be much more insoluble as compared to the other $\mathrm{AnO}_{2} \mathrm{OH}$ compounds. This can be explained as an experimental error in the measured solubility or as a mistake in the chemical description of the considered system, i.e. equilibrium controlling solubility which could be $\mathrm{Pa}_{2} \mathrm{O}_{5}+\mathrm{H}_{2} \mathrm{O} \Leftrightarrow 2 \mathrm{PaO}^{3+}+6 \mathrm{OH}^{-}$. Further decision must be made on the basis of experiment. 


\section{REFERENCES}

[1] Starik I.E., Sheidina L.D., Ilmenkova L.I., Radiochimia 1, 168 (1959).

[2] Muxart R., Guillaumont R., "Compléments au nouveau traité de chimie minérale", Pascal P., Masson et al. Ed., Paris 1974.

[3] Kotrly S., Sucha L., "Chemické rovnovahy v analytické chemii (Chemical Equilibria in Analytical Chemistry)", SNTL, Prague 1988.

[4] Smith R.M., Martell E.A., "Critical Stability Constants", Plenum Press, 1977.

[5] Baes C.F., Mesmer R.E., "The Hydrolysis of cations”, John Wiley, New York 1976.

[6] Guillaumont R., Ionova G., Krupa J.C., David F., Radiochim. Acta 75, 97-103 (1996).

[7] Bratsh S.G., J. Phys. Chem. Ref. Data, 18, 1 (1986).

[8] Morss L.R., in "The chemistry of actinide elements" of Katz J.J. and Seaborg G.T., Chapman and Hall, London 1986.

[9] Allard B., Kipatsi H., Liljenzin J.O., J. Inorg. Nucl., 42, 1015-1027 (1980).

[10] Brown P.L., Sylva R.N., Ellis J., J. Chem. Soc. Dalton Trans., 723 (1985).

[11] Neck V., Kim J.I., "Solubility and Hydrolysis of Tetravalent Actinides", Forschungszentrum Karlsruhe, report FZKA 6350, 1999.

[12] Moriyama H., Pratopo M.I., Higashi K., Radiochim. Acta, 66/67, 73-79 (1994).

[13] Brown P.L., Wanner H., "Predicted formation constants using the unified theory of metal ion complex formation", OECD, NEA, Paris 1987.

[14] Sillen L.G., Martell A.E., "Stability Constants of Metal-Ion Complexes “, Spec. Publ. $\mathrm{n}^{\circ} 17$, the Chemical Society, London 1964.

[15] Högfeldt E., "Stability constants of metal-ion complexes - Part A: inorganic ligands", IUPAC 1995.

[16] Inczedy J., "Analytical applications of complex equilibria”, Akademia Kiado, Budapest 1976. 
[17] Silva R.J., Bidoglio G., Rand M.H., Robouch P.B., Wanner H.J., Puigdomenech I. "Chemical Thermodynamics of Americium", NEA OECD, Elsevier, Amsterdam 1995.

[18] Itagaki H., Nakayama S., Tanaka S., Yamawaki M., Radiochim. Acta, 58/59, 61-66 (1992).

[19] Shannon R.D., Acta Cryst. A32, 751 (1976).

[20] Samsonov G.V., "Handbook of the physicochemical properties of the elements", Plenum press, 1968.

[21] Vlcek A.A., "Struktura a vlastnosti koordinacnich sloucenin (Structure and properties of the coordination compounds)", CSAV, Prague 1966.

[22] Katz J.J., Seaborg G.T., Morss L.R., Ed., Chapman and hall, London, 1986

[23] Trubert D., Le Naour C., Jaussaud C., J. Sol. Chem., 31, 261 - 277 (2002).

[24] Fourest B., Perrone J., Tarapcik P., Giffaut E., to be published in J. Sol. Chem..

[25] Grenthe I., Fuger J., Konings R.J.M., Lemire R.I., Muller A.B., Nguyen-Trung C., Wanner H., "Chemical Thermodynamics of Uranium", NEA OECD, North-Holland, Amsterdam 1992.

[26] Ure A.M. and Davidson C.M. „Chemical Speciation in the Environment“, Blackie Academic \& Professional, Glasgow 1995.

[27] Allard B., in "Actinides in perspectives" Edelstein N. Ed., Pergamon Press, 1982, pp. $553-580$.

[28] Rai D., Strickert R.G., Moore D.A., Ryan J.L., Radiochim. Acta, 33, 201-206 (1983).

[29] Duplessis J., Guillaumont R., Radiochem. Radioanal. Letters, 31 (4-5), 293-302 (1977)

[30] Fujiwara K., Yamana H., Fujii T., Moriyama H., Radiochim. Acta, 90, 857 (2002).

[31] Fujiwara K., Yamana H., Fujii T., Moriyama H., Radiochim. Acta, 91, 345 (2003). 


\section{FIGURE CAPTIONS}

Fig. 1: Solubility product $\left(\mathrm{K}_{\mathrm{s}}\right)$ treated by applying the Brown - Wanner theory for hydrolysis, plotted as a function of the parameter X.

Fig. 2: $\log \beta_{\mathrm{n}}$ versus $\log \mathrm{K}_{\mathrm{s}}$; grey squares correspond to interpolated values for the elements Ti, $\mathrm{Pa}, \mathrm{Zr}$, Th, Hf, $\mathrm{Pu}, \mathrm{U}, \mathrm{Np}, \mathrm{Ce}$.

Fig. 3 : Calculated solubility of protactinium as a function of $\mathrm{pH}$ and redox conditions.

The used equilibrium constants are described in part IV. 
Table 1 : Data selected for the application of the Brown-Wanner theory.

$\beta_{\mathrm{i}}$ corresponding to the equilibrium: $\mathrm{M}^{\mathrm{n}+}+\mathrm{i} \mathrm{OH}^{-} \Leftrightarrow \mathrm{M}(\mathrm{OH})_{\mathrm{i}}^{(\mathrm{n}-\mathrm{i})^{+}}$

$\mathrm{K}_{\mathrm{s}}$ corresponding to the equilibrium: $\left\{\mathrm{M}(\mathrm{OH})_{\mathrm{n}}\right\}_{\mathrm{s}} \Leftrightarrow\left[\mathrm{M}^{\mathrm{n}+}\right]\left[\mathrm{OH}^{-}\right]^{\mathrm{n}}$

\begin{tabular}{|c|c|c|c|c|c|c|c|}
\hline$-\operatorname{LogK}_{\mathrm{s}}$ & $\log \beta_{1}$ & $\log \beta_{2}$ & $\log \beta_{3}$ & $\log \beta_{4}$ & Reference & Element & $\mathbf{X}$ \\
\hline 7.71 & 2.3 & 3.6 & 4.8 & & & $\operatorname{Ag}(\mathrm{I})$ & 19.37 \\
\hline 32.3 & 9.01 & 18.7 & 27.0 & 33.0 & & $\mathrm{Al}(\mathrm{III})$ & 70 \\
\hline 27.5 & 7.6 & 13.9 & 16.3 & 18.9 & {$[28] ;[12]$} & Am(III) & 51.56 \\
\hline 47.5 & 15.5 & 29.0 & 42.0 & 44.2 & & $\mathrm{Au}(\mathrm{III})$ & \\
\hline 3.6 & 0.6 & & & & & $\mathrm{Ba}(\mathrm{II})$ & 8.39 \\
\hline 21.0 & 8.6 & 14.4 & 18.8 & 18.6 & & $\mathrm{Be}(\mathrm{II})$ & 65.31 \\
\hline 38.53 & 12.9 & 24.0 & 33.1 & 34.2 & & $\mathrm{Bi}(\mathrm{III})$ & 96.56 \\
\hline 5.19 & 1.3 & & & & & $\mathrm{Ca}(\mathrm{II})$ & 12 \\
\hline 14.2 & 3.9 & 7.7 & 10.3 & 12.0 & & $\mathrm{Cd}(\mathrm{II})$ & 33.73 \\
\hline 23.2 & 5.7 & & & & & $\mathrm{Ce}(\mathrm{III})$ & 43.08 \\
\hline 50.4 & 14.9 & 27.9 & & & & $\mathrm{Ce}(\mathrm{IV})$ & 99.42 \\
\hline 14.2 & 4.3 & $8 ; 4$ & 9.7 & 10.2 & & $\mathrm{Co}(\mathrm{II})$ & 37.22 \\
\hline 44.5 & 13.52 & & & & & $\mathrm{Co}(\mathrm{III})$ & 100.62 \\
\hline 30.0 & 10.2 & 18.3 & & & & $\mathrm{Cr}(\mathrm{III})$ & 83.01 \\
\hline 14.7 & & & & & & $\mathrm{Cu}(\mathrm{I})$ & 56.71 \\
\hline 19.32 & 6.3 & 10.7 & 14.2 & 16.4 & & $\mathrm{Cu}(\mathrm{II})$ & 49.62 \\
\hline 26.3 & 6.1 & 11.63 & 16.59 & 20.7 & & $\mathrm{Eu}(\mathrm{III})$ & 46.4 \\
\hline 15.10 & 4.5 & 7.4 & 10.0 & 9.60 & & $\mathrm{Fe}(\mathrm{II})$ & 34.99 \\
\hline 38.8 & 11.8 & 22.3 & 30.0 & 34.4 & & $\mathrm{Fe}(\mathrm{III})$ & 86.83 \\
\hline \multirow[t]{2}{*}{37.0} & 11.4 & 22.1 & 31.7 & 39.4 & & $\mathrm{Ga}(\mathrm{III})$ & 96.04 \\
\hline & 9.71 & & & & [15] & $\mathrm{GaO}(\mathrm{I})$ & \\
\hline 54.8 & 13.7 & 25.6 & 36.0 & 45.3 & & Hf(IV) & 105.68 \\
\hline 25.4 & 10.6 & 21.8 & 20.9 & & & $\mathrm{Hg}(\mathrm{II})$ & 73.61 \\
\hline 23.7 & 8.7 & & & & & $\mathrm{Hg} 2$ & \\
\hline \multirow[t]{2}{*}{35.9} & 10.0 & 20.2 & 29.6 & 33.9 & & $\operatorname{In}(\mathrm{II})$ & 76.88 \\
\hline & -0.5 & & & & & $\mathrm{~K}(\mathrm{I})$ & 1.58 \\
\hline \multirow[t]{2}{*}{22.7} & 5.5 & 10.0 & 15.0 & 18.0 & [15] & $\mathrm{La}(\mathrm{III})$ & 42.29 \\
\hline & 0.36 & & & & & $\operatorname{Li}(\mathrm{I})$ & 5.48 \\
\hline 10.74 & 2.6 & & & & & $\operatorname{Mg}(\mathrm{II})$ & 19.43 \\
\hline \multirow[t]{3}{*}{12.8} & 3.4 & 5.8 & 7.2 & 7.7 & & $\mathrm{Mn}(\mathrm{II})$ & 27.32 \\
\hline & 13.5 & 26.5 & 38.7 & & & $\mathrm{MoO} 2(\mathrm{II})$ & \\
\hline & -0.2 & & & & & $\mathrm{Na}(\mathrm{I})$ & 3.06 \\
\hline 14.5 & 4.6 & & & & & $\mathrm{Ni}(\mathrm{II})$ & 38.02 \\
\hline 53.0 & 13.2 & 25.2 & 36.4 & 46.1 & [15] & $\mathrm{Np}(\mathrm{IV})$ & 99.42 \\
\hline 8.68 & 3.3 & 5.58 & & & [18] & $\mathrm{NpO} 2(\mathrm{I})$ & \\
\hline \multirow[t]{2}{*}{22.7} & 9.1 & 17.8 & 23.0 & 21.37 & [9] & $\mathrm{NpO} 2(\mathrm{II})$ & \\
\hline & & & & & & $\mathrm{Pa}(\mathrm{V})$ & 171.06 \\
\hline 53.4 & 14.8 & 28.0 & 40.5 & 51.4 & & $\mathrm{~Pa}(\mathrm{IV})$ & 106.06 \\
\hline 16.0 & 8.0 & 21.0 & & & & $\mathrm{PaO} 2$ & \\
\hline
\end{tabular}




\begin{tabular}{|c|c|c|c|c|c|c|c|}
\hline 16.1 & 6.3 & 10.9 & 13.9 & 14.8 & [15] & $\mathrm{Pb}(\mathrm{II})$ & 48.65 \\
\hline 64.0 & & & & & & $\mathrm{~Pb}(\mathrm{IV})$ & 163.92 \\
\hline 31.0 & 13.0 & 25.8 & 35.4 & 42.2 & & $\operatorname{Pd}(\mathrm{II})$ & 94.13 \\
\hline 26.5 & 7.2 & & & & & $\mathrm{Pu}(\mathrm{III})$ & 50 \\
\hline 58.0 & 13.5 & 25.7 & 36.7 & 46.5 & [30] & $\mathrm{Pu}(\mathrm{IV})$ & 100.9 \\
\hline 8.6 & 4.3 & 9.0 & & & & $\mathrm{PuO} 2(\mathrm{I})$ & \\
\hline 22.7 & 8.5 & 17.0 & 25.0 & 29.0 & & $\mathrm{PuO} 2(\mathrm{II})$ & \\
\hline 41.4 & & & & & & $\mathrm{Sb}(\mathrm{III})$ & 105.1 \\
\hline 32.7 & 9.7 & 18.3 & 25.9 & 30.0 & & $\mathrm{Sc}(\mathrm{III})$ & 74.05 \\
\hline 26.2 & 10.6 & 20.9 & 25.4 & & & $\mathrm{Sn}(\mathrm{II})$ & 81.31 \\
\hline 56.0 & 13.51 & 28.19 & 42.88 & 58.03 & [15] & $\mathrm{Sn}(\mathrm{IV})$ & 109.16 \\
\hline 4.0 & 0.8 & & & & & $\operatorname{Sr}(\mathrm{II})$ & 10.61 \\
\hline 54.2 & 14.05 & 27.41 & 38.22 & 47.34 & & Th(IV) & 90.32 \\
\hline 35.0 & 11.8 & & & & & Ti(III) & 86.83 \\
\hline 58.3 & 18.3 & 34.9 & 47.7 & 58.7 & & Ti(IV) & 139.81 \\
\hline 29.0 & 13.7 & & & & & TiO(II) & \\
\hline 45.2 & 13.4 & 26.4 & 38.7 & 41.0 & & Tl(III) & 98.74 \\
\hline 53.9 & 13.46 & 25.4 & 36.2 & 45.7 & [31] & U(IV) & 96.6 \\
\hline 22.4 & 8.8 & 17.7 & 21.8 & $23 ; 0$ & [23] & UO2(II) & \\
\hline 34.3 & 11.7 & & & & & $\mathrm{~V}(\mathrm{III})$ & 86.83 \\
\hline 23.5 & 8.33 & 18.31 & & & & $\mathrm{VO}(\mathrm{II})$ & \\
\hline \multirow[t]{2}{*}{13.34} & 10.7 & 20.7 & 26.1 & 25.7 & & $\mathrm{VO} 2(\mathrm{I})$ & \\
\hline & 12.5 & 25.5 & 38.0 & & & WO2(II) & \\
\hline 23.2 & 6.3 & 11.6 & 16.0 & & & $\mathrm{Y}(\mathrm{III})$ & \\
\hline 15.7 & 5.0 & 11.1 & 13.6 & 14.8 & & $\mathrm{Zn}(\mathrm{II})$ & 37.22 \\
\hline 54.1 & 14.3 & 26.3 & 37.0 & 46.0 & & $\mathrm{Zr}(\mathrm{IV})$ & 104.03 \\
\hline 48.2 & & & & & & $\mathrm{ZrO}$ & \\
\hline 34.3 & 11.7 & & & & & V(III) & 86.83 \\
\hline
\end{tabular}


Table 2: Our predictions for the hydrolysis and solubility constants of Pa(IV).

\begin{tabular}{|c|c|c|c|c|c|c|c|}
\hline & $\begin{array}{l}\text { Brown- } \\
\text { Wanner }\end{array}$ & \multicolumn{2}{|c|}{$\log K_{S}$ vs. $\log \beta_{i \cdot}$} & \multicolumn{2}{|c|}{$\log K_{\mathrm{S}} / \mathrm{z}$ vs. $\log \beta_{\mathrm{i}}$} & HSE & Experimental \\
\hline$-\log K_{S}$ & $45 \pm 8$ & 53.4 & $46 \pm 6$ & 53.4 & $58.8 \pm 4.8$ & 52.9 & 53.4 \\
\hline $\log \beta_{1}$ & $14.1 \pm 1.5$ & $17.1 \pm 1.9$ & 14.8 & $12.5 \pm 1.5$ & 14.8 & 14.1 & 14.8 \\
\hline $\log \beta_{2}$ & $27.5 \pm 1.5$ & $32.5 \pm 2.5$ & $27.5 \pm 2.5$ & $24 \pm 2.5$ & $27 \pm 3$ & 25.9 & 28.0 \\
\hline $\log \beta_{3}$ & $39 \pm 3$ & $44 \pm 3$ & $37.5 \pm 3$ & $34 \pm 3.5$ & $38 \pm 3.5$ & 37.3 & 40.5 \\
\hline $\log \beta_{4}$ & $48 \pm 3$ & $52.5 \pm 5$ & $45 \pm 5$ & $39 \pm 6$ & $45 \pm 6$ & 47.9 & 51.4 \\
\hline
\end{tabular}

the data initially chosen for estimates in a given column being in bold 
Table 3 : Predicted hydrolysis and solubility constants of $\mathrm{Pa}(V)$. (The designation $\beta_{i}$ means $i$-step of complexation starting from species given in the first column).

\begin{tabular}{|l|l|l|l|l|c|c|}
\hline Starting & & & & & & \\
species & $\log \beta_{\mathbf{1}}$ & $\log \beta_{\mathbf{2}}$ & $\log \beta_{\mathbf{3}}$ & $\log \beta_{\mathbf{4}}$ & $-\log \mathbf{K}_{\mathbf{S}}$ & Method \\
\hline $\mathbf{P a O}_{\mathbf{2}}{ }^{+}$ & 9.6 & 18.6 & 23.4 & 23.0 & 12.0 & $\mathrm{HSE}$ \\
\hline $\mathbf{P a O}_{\mathbf{2}}^{+}$ & 10.0 & 19.1 & 25 & & $16^{*}$ & $\mathrm{CSC}$ \\
\hline $\mathbf{P a O}^{\mathbf{3}}$ & 10.4 & 19.7 & 27 & 34.5 & $34^{*}$ & $\mathrm{CSC}$ \\
\hline
\end{tabular}

* experimental data 
Table 4 : Comparison of solubility products predicted or measured for An(IV).

\begin{tabular}{|c|c|c|c|c|c|}
\hline Element & $\begin{array}{c}\text { Experimental } \\
\text { (Table 1) }\end{array}$ & $\begin{array}{c}\text { Brown- } \\
\text { Wanner } \\
{[13]}\end{array}$ & $\begin{array}{r}\text { Neck } \\
\\
{[11]}\end{array}$ & $\begin{array}{c}\text { Allard- } \\
\text { Kipatsi- } \\
\text { Liljenzin [9] }\end{array}$ & $\begin{array}{l}\text { Calculations by } \\
\text { HSE method } \\
\text { (present work) }\end{array}$ \\
\hline $\mathbf{P u}$ & 58.0 & 50.6 & 58.7 & 55.2 & 54.1 \\
\hline $\mathbf{N p}$ & 53.0 & 49.6 & 56.4 & 53.2 & 53.8 \\
\hline $\mathbf{U}$ & 53.9 & 48.6 & 55.0 & 54.0 & 53.3 \\
\hline Th & 54.2 & 47.3 & 52.3 & - & 52.0 \\
\hline $\mathbf{P a}$ & 53.4 & 48.2 & - & - & 52.9 \\
\hline
\end{tabular}

